\title{
Peningkatan Retensi dan Hasil Belajar Siswa melalui Penerapan Guided Discovery Berbantu Puzzle Word Game untuk Kelas X SMA
}

\section{The Improvement of the Students' Retention and Achievement by using Guided Discovery and Puzzle Word Game for Grade X Students}

\author{
HEPHI MEILINDA ${ }^{1}$, RIEZKY MAYA PROBOSARI $^{1}$, YUDI RINANTO ${ }^{1}$ \\ ${ }^{1}$ Pendidikan Biologi, Fakultas Keguruan dan Ilmu Pendidikan, Universitas Sebelas Maret. Jl. Ir. Sutami No.36A, Jebres, Kota Surakarta, \\ Jawa Tengah 57126, Indonesia \\ *Corresponding authors: hephimei 92@yahoo.com
}

Manuscript received: ......... Revision accepted:

\begin{abstract}
This study was aimed to improve retension and achievement student in X IMERSI IPA 2 class of SMA Negeri I Karanganyar through the implementation of Guided Discovery by the use Puzzle Word Game. This research was a classroom action research that divided into several cycles, each cycle includes four stages: planning, action, observation, and reflection. The subject of this research is the students of X Imersi IPA 2 class of SMA Negeri I Karanganyar in academic year of 2013/2014. The data are obtained through the test ( essay ) and non test (observation, interview and documentation). The data are analyzed through descriptive analytical techniques and validated through triangulation techniques. The results show that retension and students achievement is increased in Pre-cycle, Cycle I, and cycle II. The average of retension the improvement in Pre-cycle, Cycle I, and cycle II sequently are $(66,67 \% ; 85,47 \% ; 96,47 \%)$. Students achievement is viewed from the increase of students learning completeness consisting of cognitive, psychomotor, and affective. The result of percentage attainment average from cognitive aspects in Pre-cycle, Cycle I, and cycle II sequently are $(44,44 \% ; 61,11 \% ; 89 \%)$. Pshycomotor students achievement consist of three aspects, those are communicating the results of experiments and worksheets in the presentation, arranging porthopolio from the result of experiment and the benefit of Echinodermata and Mollusca in life, and observing the specimen as experiment object. The result of percentage attainment average from Pshycomotor aspects in Cycle I and cycle II sequently are $(64,12 \% ; 81,01 \%)$. Affective students achievement include of three aspects which are being meticulous in observing object from results of the experiment, being discipline in collecting worksheets, and being cooperative in a group of discussion. The result of percentage attainment average from Affective aspects in Cycle I and cycle II sequently are $(61,80 \% ; 76,23 \%)$. Based on the results of the research it can be concluded that the implementation of Guided Discovery model assisted by the use of Puzzle Word Game can improve the students retension and achievement of X Imersi IPA 2 at SMA Negeri I Karanganyar.
\end{abstract}

Keywords: Guided Discovery, Puzzle Word Game, Retension, Students’s Achievement

\section{PENDAHULUAN}

SMA Negeri I Karanganyar merupakan salah satu SMA di Kabupaten Karanganyar yang dikategorikan sebagai sekolah favorit dan unggulan. Hal ini terbukti dengan prestasi yang banyak diraih, baik akademik dan non akademik. Kegiatan observasi awal dilakukan melalui wawancara guru biologi dan siswa, dan didukung dengan data nilai hasil belajar pada proses pembelajaran biologi. Dalam hal ini, dapat diketahui bahwa siswa mengalami kesulitan dalam materi pembelajaran biologi terutama materi pembelajaran yang bersifat hafalan yang banyak menggunakan kosa kata ilmiah. Selama ini, cara belajar siswa yang cenderung kurang bermakna dan mayoritas belajar dengan cara menghafal menjadikan siswa kesulitan didalam proses belajaranya dan kemampuan mengingat (retensi) sehingga hal ini berdampak terhadap hasil belajar.

Hal tersebut sesuai dengan pendapat Raharjo (2012) bahwa proses berpikir berkaitan dengan kemampuan untuk mengingat sesuatu (memory procces) pada setiap siswa itu berbeda, dimana hal ini disesuaikan dengan kemampuan untuk menerima hal-hal yang telah dialami dari siswa yang disimpan dan dimunculkan kembali disaat proses mengingat dalam kegiatan pembelajaran.

Hasil observasi terhadap pembelajaran biologi yang dilakukan di kelas X Imersi IPA 2 SMA Negeri I Karanganyar semester II Tahun Pelajaran 2013/2014 menunjukkan bahwa rata-rata retensi siswa yakni sebesar $66,67 \%$ yang termasuk dalam kategori rendah dan berdasarkan hasil nilai ulangan harian dapat diketahui bahwa 55,56 \% memenuhi KKM (Kriteria Ketuntasan Minimal) yang telah ditetapkan yaitu 75 dan $44,44 \%$ untuk siswa yang belum mencapai KKM.

Hasil pengamatan menunjukkan bahwa proses pembelajaran di kelas X Imersi IPA 2 kurang diterapkan proses pembelajaran dengan sumber belajar yang mampu mengasah kemampuan mengingat (retensi) siswa untuk menyimpan materi agar bertahan lama dalam ingatan mengenai materi yang telah diterima selama proses pembelajaran. Retensi di dalam proses pembelajaran dapat dikembangkan dengan cara menguatkan daya ingat siswa dengan cara belajar biologi yang bermakna salah satunya yakni dengan pemilihan model pembelajaran yang tepat 
yang melibatkan peran aktif siswa dalam menemukan pengetahuan sendiri. Proses pembelajaran yang banyak melibatkan kegiatan menemukan pengetahuan sendiri salah satunya melalui model pembelajaran Guided Discovery ((Kauchak \& Eggen, 2012). Model pembelajaran Guided Discovery merupakan model pembelajaran Menurut Schunk (2012), penemuan terpimpin (guided discovery) menerapkan penalaran induktif dimana siswa bergerak aktif dalam perumusan dan pengujian hipotesis, bukan hanya membaca dan mendengarkan penjelasan guru. Peran guru adalah untuk memberikan motivasi dan mendorong siswa untuk belajar sendiri melalui pengalaman. Guru memberikan kebebasan kepada siswa untuk memecahkan masalah dalam kegiatan penemuan. Siswa melakukan kegiatan sendiri melalui observasi untuk mengeksplor kemampuan berpikir dalam menemukan kesimpulan dari materi pelajaran tertentu. Proses pembelajaran Guided Discovery menurut Veermans (2003) dari lima langkah kegiatan yaitu Orientation, Hypothesis generation, Hypothesis testing, Conclusion, dan Regulation.

\section{METODE PENELITIAN}

Penelitian adalah Penelitian Tindakan Kelas (PTK) yang bertujuan untuk mengetahui penerapan guided discovery berbantu puzzle word game untuk meningkatkan retensi siswa kelas X Imersi IPA 2 SMA Negeri 1 Karanganyar dan mengetahui penerapan guided discovery berbantu puzzle word game untuk meningkatkan kemampuan hasil belajar siswa kelas X Imersi IPA 2 SMA Negeri 1 Karanganyar.

Prosedur penelitian mengikuti model yang dikembangkan oleh Kemmis dan Robin MC Taggart dalam Arikunto (2008) yang berupa model spiral yaitu dalam satu siklus terdiri dari tahap perencanaan, tindakan, observasi dan refleksi. Pelaksanaan tindakan siklus dilaksanakan setelah observasi pra-siklus.

Penerapan tindakan berupa Guided Discovery berbantu Puzzle Word Game dilaksanakan dalam dua siklus yaitu siklus I dan siklus II. Siklus I direncanakan dan dilaksanakan berdasarkan hasil analisis observasi prasiklus, siklus II direncanakan dan dilaksanakan berdasarkan refleksi siklus I, sehingga penerapan Guided Discovery berbantu Puzzle Word Game meningkatkan retensi dan hasil belajar.

\section{HASIL DAN PEMBAHASAN}

Hasil penelitian menunjukkan perbandingan rata-rata retensi siswa tingkat pada prasiklus, siklus I, dan siklus II disajikan dalam Gambar 1.

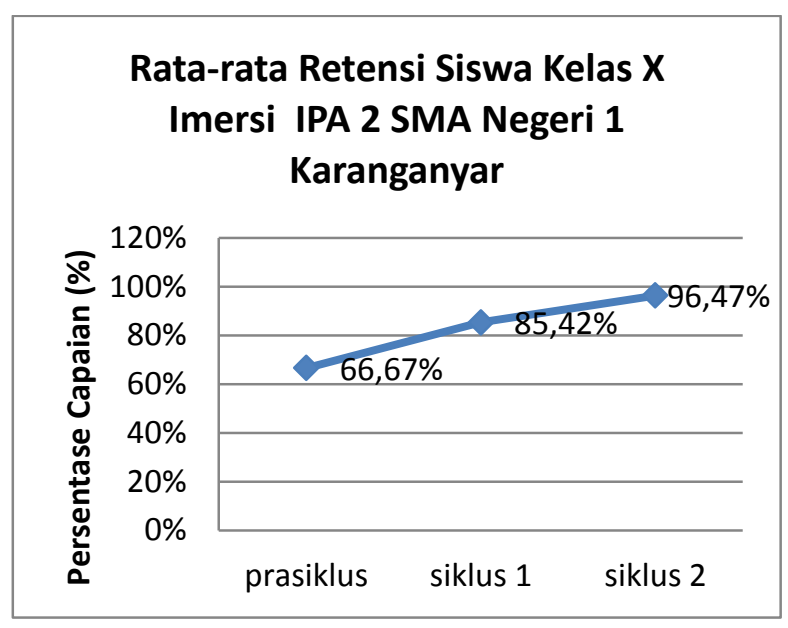

Gambar 1. Perbandingan hasil capaian rata-rata retensi siswa pada Pra Siklus, Siklus I, dan Siklus II

Gambar 1 menunjukkan bahwa skor retensi siswa mengalami peningkatan dari prasiklus hingga siklus II. Perbandingan tingkat skor postest dan retest siswa pada prasiklus, siklus I, dan siklus II disajikan dalam Tabel 1.

Tabel 1. Skor Capaian postest dan pretest siswa pada prasiklus, siklus I, dan siklus II

\begin{tabular}{ccccc}
\hline \multirow{2}{*}{ No } & Ket & \multicolumn{3}{c}{ Capaian Presentase (\%) } \\
\cline { 3 - 5 } & & Pra-siklus & Siklus I & Siklus II \\
\hline $\mathbf{1}$ & Postest & 66,67 & 91,93 & 85,71 \\
$\mathbf{2}$ & Pretest & & 83,74 & 80 \\
\hline
\end{tabular}

Hasil capaian hasil belajar ranah pengetahuan rata-rata siswa pada pra siklus, siklus I, dan siklus II pada Gambar 2.

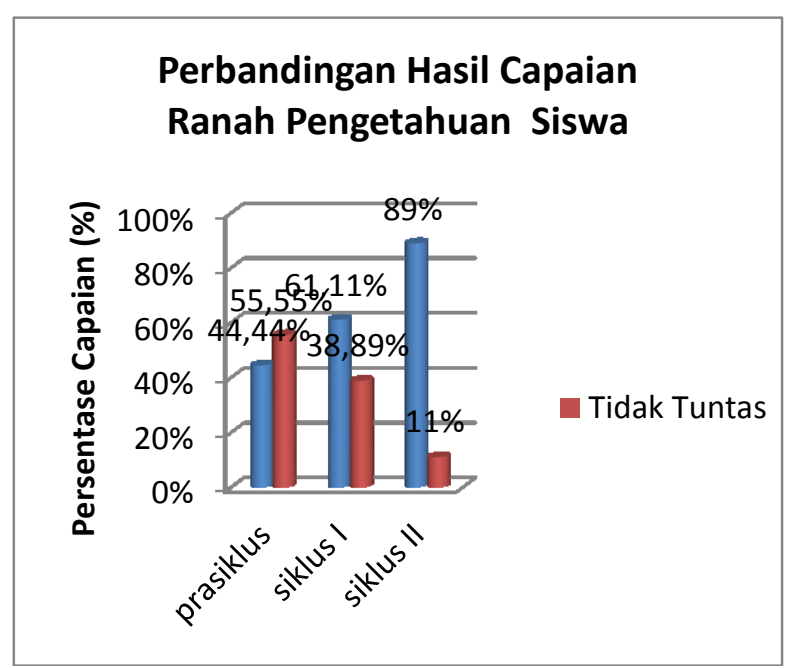

Gambar 2. Perbandingan hasil capaian ranah pengetahuan siswa pada pra siklus, siklus I, siklus II dan Siklus III

Gambar 2 menunjukkan bahwa hasil capaian ranah pengetahuan siswa mengalami peningkatan dari prasiklus hingga siklus II. Perbandingan rata-rata capaian hasil 
belajar siswa pada prasiklus, siklus I, dan siklus II disajikan dalam Tabel 2.

Tabel 2. Perbandingan Rata-Rata Capaian Hasil Belajar Siswa pada Prasiklus, Siklus I, dan Siklus II

\begin{tabular}{ccccc}
\hline \multirow{2}{*}{ No } & \multirow{2}{*}{ Ket } & \multicolumn{3}{c}{ Capaian Presentase (\%) } \\
\cline { 3 - 5 } & & Pra-siklus & Siklus I & Siklus II \\
\hline $\mathbf{1}$ & Tuntas & 44,44 & 61,11 & 89 \\
$\mathbf{2}$ & Belum & 55,56 & 38,89 & 11 \\
& Tuntas & & & \\
\hline
\end{tabular}

Hasil capaian hasil belajar ranah keterampilan rata-rata siswa pada siklus I, dan siklus II pada Gambar 3

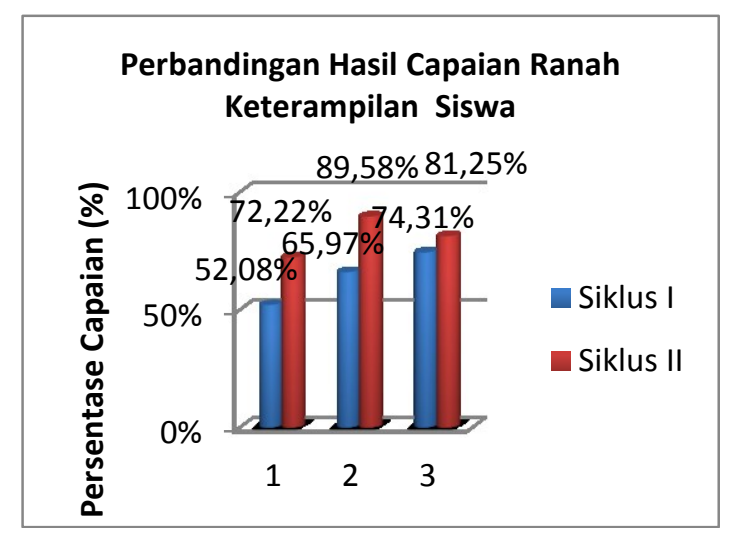

Indikator : 1. Mengkomunikasikan hasil diskusi melalui presentasi di depan kelas 2. Menyusun Portofolio dari hasil penemuan dan peranan Mollusca dan Echinodermata bagi kehidupan 3. Mengamati specimen yang dijadikan objek penemuan.

Gambar 3. Hasil Capaian Hasil Belajar Ranah Keterampilan Rata-Rata Siswa pada Siklus I, dan Siklus II

Gambar 3 menunjukkan bahwa hasil capaian ranah keterampilan siswa mengalami peningkatan dari siklus I hingga siklus II. Perbandingan rata-rata capaian hasil belajar siswa pada siklus I, dan siklus II disajikan dalam Tabel 3.

Tabel 3. Perbandingan Rata-Rata Capaian Hasil Belajar Siswa pada Siklus I, dan Siklus II

\begin{tabular}{ccc}
\hline \multirow{2}{*}{ Indikator } & \multicolumn{2}{c}{ Capaian Presentase (\%) } \\
\cline { 2 - 3 } & Siklus I & Siklus II \\
\hline $\mathbf{1}$ & $52,08 \%$, & $72,22 \%$ \\
$\mathbf{2}$ & $65,97 \%$ & $89,58 \%$ \\
$\mathbf{3}$ & $74,31 \%$ & $81,94 \%$ \\
\hline Total & $192,36 \%$ & $243,75 \%$ \\
\hline Rata-rata & $64,12 \%$ & $81,25 \%$ \\
\hline
\end{tabular}

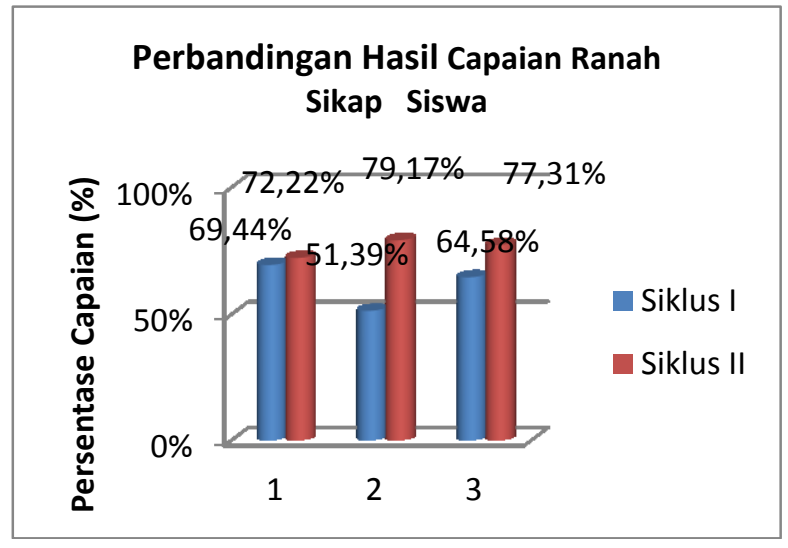

Indikator :1Teliti dalam menuliskan informasi tentang spesies yang diamati 2. Disiplin dalam kegiatan pembelajaran 3. Bekerjasama dalam kegiatan diskusi kelompok

Gambar 4. Hasil Capaian Hasil Belajar Ranah Sikap Rata-Rata Siswa Siklus I dan Siklus II

Gambar 4 menunjukkan bahwa hasil capaian ranah keterampilan siswa mengalami peningkatan dari siklus I hingga siklus II. Perbandingan rata-rata capaian hasil belajar siswa pada siklus I, dan siklus II disajikan dalam Tabel 4.

Tabel 4. Perbandingan Rata-Rata Capaian Hasil Belajar Siswa pada Siklus I, dan Siklus II

\begin{tabular}{ccc}
\hline \multirow{2}{*}{ Indikator } & \multicolumn{2}{c}{ Capaian Presentase (\%) } \\
\cline { 2 - 3 } & Siklus I & Siklus II \\
\hline $\mathbf{1}$ & $69,44 \%$ & $72,22 \%$ \\
$\mathbf{2}$ & $51,39 \%$ & $79,17 \%$ \\
$\mathbf{3}$ & $64,58 \%$ & $80,55 \%$ \\
\hline Total & $185,41 \%$ & 231,96 \\
\hline Rata-rata & $61,81 \%$ & $77,31 \%$ \\
\hline
\end{tabular}

Pelaksanaan model pembelajaran PBL terdiri dari 5 fase yaitu Orientation, Hypothesis generation, Hypothesis testing, Conclusion, dan Regulation. Tahap Hypothesis testing, Hipotesis yang diperoleh dari proses pemunculan dugaan sementara belum diketahui kebenarannya, sehingga perlu dilakukan pengujian hipotesis. Aktivitas siswa pada tahapan tersebut antara lain; merancang dan melakukan percobaan, mengumpulkan data dari literature yang sesuai, kemudian menafsirkan hasilnya.

Tahap Conclusion siswa meninjau kembali hipotesis awal dengan mencocokkan fakta-fakta yang telah diperoleh dari pengujian hipotesis. Siswa memutuskan fakta yang sepaham dengan prediksi yang diperolah dari hipotesis kemudian menyajikan kesimpulan.

Tahap terakhir Regulation, siswa dan guru mengevaluasi kegiatan pembelajaran yang telah dilakukan. 
Guru membandingkan beberapa kesimpulan dari siswa melalui presentasi, kemudian diputuskan kesimpulan yang tepat sebagai konsep yang ditemukan atau dihasilkan dalam pembelajaran.

Tahap Orientation, pada kegiatan ini guru memberikan suatu fenomena. Pada siklus I dengan menunjukkan video untuk menemukan ciri-ciri, klasifikasi dan contoh berbagai macam hewan yang masuk ke dalam filum Mollusca. Sedangkan kegiatan siswa adalah mengamati fenomena masalah yang disajikan oleh guru. Pada kegiatan ini tidak semua siswa memperhatikan, beberapa siswa tidak memperhatikan fenomena yang disajikan oleh guru karena pembelajaran biologi berada di jam terakhir sehingga beberapa siswa mengantuk. Sedangkan pada siklus II dengan menunjukkan video filum Echinodermata, siswa mengamati fenomena masalah yang disajikan oleh guru. Pada kegiatan ini tidak semua siswa memperhatikan, ada siswa yang tidak memperhatikan fenomena yang disajikan oleh guru. Tetapi jika dibandingkan siklus I pada siklus II siswa yang tidak memperhatikan lebih sedikit.

Sintaks Hypothesis generation, pada siklus I guru membimbing siswa untuk mendiskusikan judul, rumusan masalah dalam bentuk pertanyaan, tujuan percobaan berdasarkan pengamatan terhadap permasalahan yang terkait dengan tujuan pembelajaran yaitu ciri-ciri, klasifikasi dan contoh berbagai macam hewan yang masuk ke dalam filum Mollusca. Pada tahapan ini kegiatan siswa adalah secara berkelompok mendiskusikan judul, rumusan masalah dalam bentuk pertanyaan seperti bagaimana ciriciri filum Echinodermata, bagaimana klasifikasi dari Filum Echinodermata dan apa contoh spesies dari filum Echinodermata, tujuan percobaan berdasarkan pengamatan terhadap permasalahan. Pada tahap ini beberapa siswa belum paham tentang intruksi dari guru, sehingga guru harus mengulangi intruksi kembali. Pada siklus II dengan tahapan yang sama akan tetapi dengan sub materi Echinodermata. Siswa sudah mulai paham tentang intruksi dari guru, berdasarkan pengalaman di pembelajaran sebelumnya yaitu pada siklus I. Siswa terlihat sudah terbiasa dalam menyusun permasalahan sehingga hampir semua siswa aktif dalam mengungkapkan pendapat, ide, dan tanggapan terhadap fenomena yang disajikan guru.

Sintak Hypothesis testing, pada tahapan ini guru membimbing siswa untuk membuat hipotesis berdasarkan rumusan masalah yang dibuat yaitu bagaimana ciri-ciri filum Mollusca, bagaimana klasifikasi dari Filum Mollusca dan apa contoh spesies dari filum Mollusca. Siswa secara berkelompok membuat hipotesis berdasarkan rumusan masalah yag dibuat. Siswa merasa kebingungan untuk membuat hipotesis, sehingga guru menjelaskan kembali tentang maksud dari hipotesis. Setelah dijelaskan berulangulang sehingga siswa paham maksud dari membuat hipotesis. Pada siklus II siswa sudah paham untuk membuat hipotesis, hal ini dikarenakan pada siklus I siswa sudah dijelaskan bagaimana membuat hipotesis, kemudian guru membimbing siswa untuk merancang penemuan meliputi menentukan alat, bahan dan langkah kerja sebagai usaha untuk mencari jawaban atas pertanyaan yang telah dibuat. Guru juga membimbing siswa untuk mengambil alat-alat dengan melakukan bon alat yang diperlukan untuk melakukan percobaan. Guru membimbing siswa melakukan pengamatan terhadap filum Molusca sesuai dengan rancangan percobaan yang telah disusun pada setiap kelompok. Pada sintak ini siswa menulis rancangan percobaan pada LKS, perwakilan dari kelompok maju ke depan dengan membawa bon alat untuk mengambil alatalat yang diperlukan untuk pengamatan. Kemudian siswa mengamati awetan Mollusca . Pada saat pengamatan sebagian siswa merasa keberatan untuk melakukan pengamatan dikarenakan awetan yang diamati berbau menyengat yang tidak sedap. Pada siklus II saat pengamatan sebagian siswa sudah merasa tidak keberatan untuk melakukan pengamatan dikarenakan awetan yang diamati merupakan hewan basah yang belum diawetkan menggunakan formalin seperti pada pengamatan siklus I.

Sintak menguji hipotesis dengan melakukan percobaan, Kegiatan pada tahap ini guru membimbing siswa untuk mengeksplorasi sebanyak-banyaknya sumber data yaitu filum Echinodermata untuk mendapatkan informasi yang dibutuhkan atas usaha menjawab pertanyaan atau rumusan masalah yang telah disusun. Guru juga membimbing siswa untuk mencatat semua informasi yang telah diperoleh dari percobaan pada LKS. Kegiatan yang dilakukan siswa pada tahap ini adalah siswa mengeksplorasi sebanyakbanyaknya tentang filum Echinodermata melalui pengamatan awetan, literatur baik buku dan internet. Siswa juga menulisakan jawaban dari pertanyaan yang ada di LKS. Pada siklus II Siswa juga menulisakan jawaban dari pertanyaan yang ada di LKS. guru membimbing siswa untuk menjawab pertanyaan berdasarkan data yang diperoleh dari kegiatan percobaan dengan menuliskan jawaban pada LKS. Kegiatan siswa pada tahap ini secara berkelompok menuliskan jawaban pertanyaan pada LKS dengan menghubungkan pengalaman yang telah dimiliki dengan data dan informasi yang diperoleh pada kegiatan percobaan. Dalam kegiatan ini siswa bekerjasama dengan cukup baik. Pada siklus II siswa bekerjasama dengan cukup baik.

Untuk membantu menguji ingatan siswa dan untuk membantu proses pembelajaran ditambahkan dengan game yaitu Puzzle Word Game, sebelum dilakukan game guru mendemonstrasikan cara melakukan permainan mengenai nama-nama ilmiah dari filum Mollusca melalui Puzzle Word Game. Kemudian guru membimbing siswa untuk melakukan permainan mengenai nama-nama ilmiah dari filum Mollusca melalui Puzzle Word Game dengan menunjukkan perwakilan kelompok. Memperhatikan demonstrasi dari guru cara melakukan permainan mengenai nama-nama ilmiah dari filum Mollusca melalui Puzzle Word Game. Melakukan permainan mengenai nama-nama ilmiah dari filum Mollusca melalui Puzzle Word Game dengan mengirimkan perwakilan kelompok. Sedangkan siswa yang tidak maju untuk tes Puzzle Word Game duduk dibelakang dengan memperhatikan siswa yang memainkan game kemudian sambil mengisi LKS yang jawabannya ada di dalam game. Beberapa siswa tidak memperhatikan. Pada siklus II masih ada siswa yang belum memperhatikan. 
Tahap Conclusion, pada tahap ini kegiatan yang dilakukan adalah guru membimbing siswa untuk menyimpulkan hasil percobaan. Guru menunjuk dan membimbing siswa secara berkelompok untuk menyampaikan hasil percobaan dan diskusi. Guru memberikan kesempatan kepada siswa kelompok lain untuk bertanya kepada kelompok presentator dan menambahkan jika ada penjelasan yang belum disampaikan oleh kelompok presentator. Guru menunjuk siswa untuk menyimpulkan hasil diskusi dan percobaan pada kegiatan pembelajaran.

Tahap Regulation ,Siswa pada tahap ini membuat kesimpulan dengan teman kelompok, setelah itu maju ke depan kelas untuk menyampaikan hasil diskusi tiap kelompok. Ketika presentasi, sebagian siswa tidak memperhatikan teman yang sedang presentasi. Kemudian waktu yang digunakan untuk presentasi terlalu menyita banyak waktu. Kemudian pada tahap ini siswa tidak ada yang ditunjuk untuk membuat hasil diskusi secara mandiri. Pada siklus II Siswa Ketika presentasi, masih ada sebagian siswa yang tidak memperhatikan teman yang sedang presentasi, ini menandakan bahwa jalannya presentasi kurang terorganisir dengan baik. Kemudian pada tahap ini siswa sudah ada yang ditunjuk untuk membuat hasil diskusi secara mandiri. Didalam kegiatan presentasi, terdapat proses menjelaskan yaitu kemampuan untuk menyatakan hasil atau alasan berdasarkan bukti dengan berupa argumentasi yang meyakinkan

Setelah semua sintak kegiatan dilakukan guru mengkonfirmasi dan merefleksi tentang materi yang dipelajari hari ini tetapi pada saat mengkonfirmasi materi kurang ditekankan, selain itu guru juga belum memperdalam kesimpulan diskusi dari LKS saat penyampaian materi. Guru dan siswa juga akan melakukan refleksi terhadap proses kegiatan pembelajaran guna memperbaiki dan menyempurnakan kegiatan pembelajaran berikutnya.

Hasil tes pada siklus I menunjukkan bahwa terjadi peningkatan yang dari pra siklus menuju siklus I. Tes retensi pada siklus I dilakukan dua kali yaitu posttest dan retest. Hasil posttest dan retest pada siklus I mengalami penurunan sebesar 8,4\%. Hal ini menunjukkan bahwa siswa memiliki retensi yang sudah cukup baik akan tetapi perlu ditingkatkan. Hasil tes hasil belajar siswa yang meliputi hasil belajar kognitif, psikomotor, dan afektif belum memenuhui KKM. Hasil belajar kognitif bisa dilihat dari prasiklus, ketika siswa melaksanakan ulangan harian dengan materi Plantae. Hasil tes kognitif pada siklus I menunjukkan peningkatan sebesar $17,22 \%$. Peningkatan dari prasiklus ke siklus I mengindikasikan bahwa dengan Guided Discovery berbantu Puzzle Word Game, siswa sudah mulai terlatih dalam proses penemuannya dengan berdiskusi pada materi mollusca sampai melakukan percobaan dan penguasaan nama ilmiah dalam materi yang mempermudah siswa dalam mengingat berbagai jenis spesies sehingga mampu diserap otak karena dikemas dalam bentuk yang permainan yang menarik.

Pada siklus II menunjukkan peningkatan yaitu guru mampu mengatasi percobaan yang dilakukan dan diskusi berjalan lancar, guru juga intens dalam membimbing siswa sehingga tidak mengalami kesulitan sehingga dapat menemukan konsep didalam pembelajaran dan mampu untuk mengerjakan tes evaluasi dengan baik tes retensi pada siklus II juga dilaksanakan dua kali yaitu posttest dan retest. Hasil posttest dan retest pada siklus II terjadi peningkatan dikarenakan siswa sudah mengenali tipe soal yang diberikan pada silkus I, sehingga pada siklus II retensi sudah baik. Hasil test pada siklus II posttest dan retest menunjukkan penurunan dari siklus I menuju siklus II yaitu $5,75 \%$. Hasil tes kognitif pada siklus II menunjukkan peningkatan $27,89 \%$ dari siklus I ke siklus II. Peningkatan dari prasiklus ke siklus I mengindikasikan bahwa dengan Guided Discovery berbantu Puzzle Word Game mampu memberikan pengalaman belajar kepada siswa dengan kegiatan pengamatan, identifikasi, pengelompokkan yang melatihkan kemampuan mengingat dan mengenali kembali dalam kegiatan diskusi yang dibimbing oleh guru sehingga mampu mengembangkan kemampuan retensi siswa. Hal ini sesuai pendapat Kauchak \& Eggen (2012) menjelaskan bahwa Guided Discovery dapat membimbing siswa mengembangkan pemahaman proses berpikir dalam pemecahan masalah sehingga menjadikan pengetahuan siswa bertahan lama atau lebih mudah diingat dengan menerapkan permainan Puzzle word game dengan menerapkan informasi yang harus dipelajari dengan menyajikan huruf secara acak kemudian di susun untuk menjadi kata yang tepat.

Secara khusus, permainan ini menekankan pada penguasaan nama ilmiah dalam materi animalia, tentunya ini untuk mempermudah siswa dalam mengingat berbagai jenis spesies sehingga mampu diserap otak karena dikemas dalam bentuk yang permainan yang menarik. Hal ini senada dengan penelitian Herlanti dkk (2007) membuktikan bahwa penggunaan multimedia dalam pembelajaran memberikan kontribusi positif pada retensi. Dalam hal ini, multimedia dalam imagery tools membuat siswa lebih lama menyimpan abstraksi konsep dalam struktur kognitif daripada pembelajaran tanpa menggunakan multimedia. Retensi dan hasil belajar siswa mengalami peningkatan selama tindakan penerapan Guided Discovery berbantu Puzzle Word Game yang memberi dampak positif dalam proses pembelajaran. Retensi menurut De porter dan Hernacki dalam Tapilouw dan Setiawan (2008) dilatihkan dan dikembangkan melalui metode yang melibatkan masalah. dan model Guided Discovery merupakan model pembelajaran konstruktivis yang mendorong siswa untuk aktif mencari pengetahuan dan pemecahan. Retensi merupakan fase didalam belajar dengan menunjukkan informasi baru yang diterima oleh memori jangka pendek untuk dipindahkan ke memori jangka panjang. Hal ini terjadi dengan pengulangan kembali, praktek, dan elaborasi, dan lain - lainnya.

Skor capaian hasil belajar psikomotor tiap siklus ditunjukkan pada gambar diagram 4.4. Berdasarkan gambar diagram tersebut, rata-rata hasil belajar psikomotor mengalami peningkatan jika dibandingkan dengan siklus I. Hal ini disebabkan pembelajaran menggunakan Guided Discovery didasarkan pada teori konstruktivis dimana 
pengalaman dan pemahaman awal siswa akan membentuk satu pengetahuan baru. Hal ini didukung oleh Kuhlthau, et al. (2007: 26) yang menyatakan bahwa dalam Guided Discovery siswa membangun sendiri apa yang sudah diketahui. Proses pembangunan diri berlangsung secara aktif, selama proses pembelajaran berlangsung.

Skor capaian hasil belajar afektif yang diperoleh melalui lembar observasi kecapakan personal menunjukkan pada siklus I ditunjukkan pada gambar diagram 4.5. Skor capaian hasil belajar afektif tersebut menunjukkan adanya peningkatan rata-rata skor capaian pada siklus II dibandingkan siklus I. Peningkatan pada hasil belajar afektif disebabkan pada proses pembelajaran menggunakan Guided Discovery, siswa terlibat langsung dalam menggali informasi melalui pengalaman, buku yang pernah dibaca serta informasi yang pernah didengar yang kemudian menjadi pengalaman awal untuk mempersiapkan metode dan material yang dipelajari. Hal ini didukung pernyataan Kuhlthau, et al. (2007) bahwa kemampuan pada saat menggali informasi dan pengalaman yang dimiliki memacu keterkaitan berbagai disiplin ilmu yang mampu memunculkan ide, solusi serta perspektif yang dipenuhi dengan proses berpikir dan kebijaksanaan seiring dengan perkembangan personal siswa serta kemampuan berpikir yang didasarkan pada pengalaman individu. Oleh karena itu, pada akhirnya hal tersebut dapat menjadi latihan untuk membangun individu yang bertanggung jawab..

Penerapan Guided Discovery berbantu Puzzle Word Game menjadikan pembelajaran bermakna dengan pengetahuan yang didapat melalui penemuan sendiri dengan mengaitkan konsep relevan pada struktur kognitif yang dimiliki siswa. Siswa SMA yang digunakan dalam penelitian ini berada pada tahap operasi formal dimana memiliki tingkat perkembangan tertentu sesuai dalam teori belajar Piaget. Hal ini senada dengan pendapat Sund dalam Rostiyah (2008) menyatakan bahwa proses belajar menitikberatkan pada proses dalam mengasimilasikan suatu konsep atau prinsip. Proses ini bertujuan untuk melatih siswa dalam menemukan sendiri pengalaman belajar yang dilakukan pada saat kegiatan pembelajaran.

\section{KESIMPULAN}

Kesimpulan penelitian ini adalah penerapan Guided Discovery berbantu Puzzle Word Game dapat meningkatkan retensi dan kemampuan berpikir kritis siswa kelas X Imersi IPA 2 SMA Negeri 1 Karanganyar Tahun Pelajaran 2013/2014.

\section{DAFTAR PUSTAKA}

Arikunto,S. (2010). Dasar-Dasar Evaluasi Pendidikan. Jakarta : Bumi Aksara.

Eggen, P., \& Kauchak, D. 2012. Strategi dan Model Pembelajaran. Jakarta: PT Indeks.

Herlanti, Y., Rustaman, N. Y., \& Setiawan, W. (2007, April). Kontribusi Wacana Multimedia Terhadap Pemahaman dan Retensi Siswa. Jurnal Pendidikan IPA: Metamorfosa , 29-38.
Raharjo, T. 2009. Memahami Perbedaan Kemampuan Daya Ingat Pada Individu Dengan Pengaruh Stimulasi Visual Dan Stimulasi Verbal.( 1), 1-11

Roestiyah, N. (2008). Strategi Belajar Mengajar. Jakarta: PT Rineka Cipta.

Schunk, D. H. (2012). Learning Theories and Educational Perspective. Yogyakarta: Pustaka Pelajar.

Tapilouw, F., \& Setiawan, W. (2008). Meningkatkan Pemahaman dan Retensi Siswa Melalui Pembelajaran Berbasis Teknologi Multimedia Interaktif. Jurnal Pendidikan Teknologi Informasi dan Komunikasi , 1 (2), 19-25.

Veermans, K. (2003). Intellegent Support For Discovery Learning. Netherland: Twente University Press. 